\title{
NUTRIENT UTILIZATION AND GROWTH PERFORMANCE OF CLARIAS GARIEPINUS FINGERLINGS FED GRADED LEVELS OF DIETARY PROTEIN
}

\author{
Idowu E.O \#1, Odeyemi D.F ${ }^{\# 2}$,Araeko O.H ${ }^{\# 3}$
}

\#1Department of Zoology and Environmental Biology, Faculty of Science, Ekiti State University, Ado Ekiti, Ekiti State, 08039422005, idowu.eunice@eksu.edu.ng

\#2Department of Science Laboratory Technology (Biotechnology Option) Faculty of Science, Ekiti State University, Ado Ekiti, Ekiti State, 08066628378, dolapo.odeyemi@eksu.edu.ng \#3Department of Zoology and Environmental Biology, Faculty of Science, Ekiti State University, Ado Ekiti, Ekiti State,

Correspondence Author: Idowu E.O, Department of Zoology and Environmental Biology, Faculty of Science, Ekiti State University, Ado Ekiti, Ekiti State. P.M.B. 5363, Ado Ekiti, Ekiti State, Nigeria. Email address: idowu.eunice@eksu.edu.ng

\section{ABSTRACT.}

Nutrient utilization and growth performance of Clarias gariepinus fingerlings fed graded levels of dietary protein were carried out in a circular plastic of $40 \mathrm{~cm}$ diameter $\times 30 \mathrm{~cm}$ deep inside the Animal House for 8 weeks. Five diets of 35, 40, 45, 50 and 55\% were tried in duplicates. The diets at different crude protein were given at $5 \%$ of their body weight to determine the growth performance. Growth rate and weight gain increased progressively with levels of dietary protein to a maximum at $40 \%$. Significant differences $(p<0.05)$ of $4.97 \pm 0.67^{b}$ to $10.1 \pm 0.45^{d}$ were recorded for growth indices. The nutrient utilization parameters had variable results among the treatments. There was no significance difference in apparent feed conversion ratio and the nitrogen metabolism but apparent protein efficiency ratio show significant variations. The overall results indicated that fish fed $40 \%$ diet performed best in weight gain, food conversion ratio and nitrogen metabolism.

Keywords: Crude protein, Clarias gariepinus, Growth, Fish meal, Soyabean meal, Nutrient utilization

\section{Corresponding Author: Idowu E.O}

\section{INTRODUCTION}

Fish is important and cheapest source of animal protein and account for about $37 \%$ of Nigeria's total protein requirement (Ndimele et al.,, 2011). Fish is an essential source of animal protein in most part of the globe because some competing protein sources of animal origin like beef have been implicated in heart diseases (Owodeinde et al.,, 2011). Fish culture which is an important source of protein and employment for many people (Gabriel et al., 2007) has been used to bridge the gap between demand and supply of fish from capture fisheries. High cost of imported fish feeds with fish meal as the primary protein source constitute $40-60 \%$ of the recurrent cost of most intensive fish farm ventures (Jamu and Ayinla, 2003). Majority of alternative protein feedstuffs have been found to be deficient in one or more essential amino acids and/or contained various quantities of anti-nutritional factors (Soltan et al.,, 2008). Blends of animal by-product meals have however been 
combined with other feed ingredients with complementary amino acid profiles to satisfy the nutritional requirements of wide range of farmed fish species (Laporte et al., 2009). Several nutritional evaluations indicated that the utilization of animal by-product blends in aquafeed could help the aquaculture industry grow into a sustainable, ecological and ethical bio- industry (Glencross et al., , 2007).

The African catfish Clarias gariepinus is a major warm water aquaculture species in Africa (Egypt, Ethiopia, Ghana, Maliand Nigeria) and Asia (China, Indonesia, Malaysia, Philippines and Thailand), and has been introduced recently in Europe (the Netherlands, Germany and Belgium) and Latin America (Brazil) (FAO, 2010; Ali, 2001).The superior performance of C. gariepinus compared with other Clarias species in terms of growth rate has probably contributed to the fact that $C$. gariepinus has been widely introduced to areas outside its natural range (Verreth et al., 1993). Previous studies have shown that Clarias gariepinus is a suitable alternative to tilapia for subsistence fish farming in Africa, and using low-grade feed composed of local agricultural byproducts, the yields of Clarias gariepinus from ponds could be as much as 2.5 times higher than those of tilapia (Hogendoorn, 1983).

Fish meal (FM) is the dominant ingredient in commercially prepared diets for many fish species. As a consequence of rapid growth in fish farming, FM prices have increased significantly in the past few years and are likely to increase further with continued growth in demand (Hardy and Tacon, 2002). As with general aquaculture nutrition, a priority area of major research is the reduction and possible elimination of FM and fish oil (Gatlin and Hardy, 2002). The uncertain future of FM availability and its potential high cost has forced to investigate alternative protein sources of good nutritional quality, which are ideally readily available and more cost effective than FM. This will reduce production costs and create a good quality product suitable for any small or large-scale fish production system.

Soybean meal (SBM) is one of the best ingredients to substitute FM (Lovell, 1988). Soybean meal is cost effective, readily available, high in protein content and has the best protein quality among plant protein feedstuffs used as alternative protein sources to FM in fish diet (Lovell 1988; Rumsey et al., 1993). However, considerable variations exist in the ability of different fish species to utilize soybean protein. Hypotheses explaining this lack of success include less than optimal amino acid (AA) balance in SBM protein and the presence of residual levels of trypsin inhibitors (Webster et al.,, 1992; Webster et al.,,1995; Refstie et al.,,1997; Refstie et al.,,,1998). Rendered animal protein, such as meat and bone meals (MBM), poultry by-product meal and blood meal derived from animal rendering plants and waste recycling process, have considerable potential in fish feeds (Fowler, 1991; Bureau et al., 2000; Millamena, 2002; Fasakin et al.,2005). These animal by-products have long been used in compound feeds for terrestrial monogastric animals such as poultry and swine (Parsons et al., 1997). Many studies in recent years have also shown that animal protein ingredients are useful for fish feed formulation and comparatively less expensive than FM (Stevens 1994; Rodriguez 1996; Bureau et al., 1999; Abdel-Warith et al., 2001). Rendered animal protein ingredients are good sources of AAs, with high protein content, total digestible dry matter and digestible energy similar to FM (Bureau et al.,, 1999, 2000).

Meat and bone meal (MBM) are potential alternative animal protein sources because of their high protein contents and low price compared with the FM (Tacon and Jackson, 1985). Generally, the substitution of MBM for FM by $<30 \%$ in fish feeds is suggested (Pongmaneerat and Watanabe 1991; Robaina et al., 1997; Bureau et al.,, 2000), but even higher substitute with positive results has been reportedin gilthead sea bream (Alexis 1997) and rainbow trout (Watanabe et al., 1993). Previous studies have shown that PBM cannot substitute more than 50\% of FM in fish diets (Gallagher and Degani, 1988; Fowler 1991; Stevens 1994).

Findings have shown the nutritional value of many alternative feed ingredients as a protein sources. Several researches have shown that alternative protein sources derived from grains including corn, wheat, barley, soybean, cotton seed, fishmeal, and animal by products such as mechanically 
deboned meal, poultry by-product meal, meat and bone meal, maggot, Bambara groundnut can be used to formulate nutritious aquaculture feed at various levels of inclusions in different feeds. For instance, (Oso et al., 2013) showed that Clarias gariepinus fingerlings fed up to $75 \%$ of Bambara groundnut in fish feed was satisfactorily acceptable without affecting growth and feed utilization. The Clarias gariepinus fed with $75 \%$ diets showed superior feed conversion ratio. This agreed with the findings of (Davies and Gouvenia, 2010) who worked on the dietary nitrogen utilization in Clarias gariepinus fed oil seed meal diets under sub- optimal growth condition consistent with a restricted regime. It was stated that fish fed the experimental diets showed superior feed conversion ratio.

\section{MATERIALS AND METHODS}

\section{Purchase of Fish Species and Acclimatization}

A total of One hundred and fifty (150) fingerlings of Clarias gariepinus were purchased from a local fish market in Ekiti state and were acclimatized for two weeks, they were fed with commercial feed pellet of $1.8 \mathrm{~mm}$ at $5 \%$ of their average body weight per day. Clarias gariepinus were randomly distributed into well label bowls filled with dechlorinated water in duplicate. The water was replaced at an interval of three days.

\section{Feeding and Monitoring}

The fingerlings Clarias gariepinus were fed with experimental feeds in duplicate bowl as the rate of $5 \%$ of their body biomass for 62days. The fishes were fed twice daily between 9.00-10.00am and 5.00-6.00pm. Water in the bowls was replaced two times a week and undigested food particles and waste products were siphoned and each bowl washed thoroughly.

\section{Procurement and Processing of Test Ingredients}

Adequate quantity of the various ingredient used for the experiment were purchased from a commercial animal feed vendor, Metrovet consultant in Ado-Ekiti. The feed ingredients like Maize, Soybeans, Fishmeal, Rice bran, Vitamin c, methionine, lysine, Salt, Groundnut oil and Starch binder were milled and stored for usage. The diets were milled and the amount of each feed ingredients were weighed separately using Pearson square method of feed formulation. The different ingredients were properly mixed together and pelleted in a local way to $1.8 \mathrm{~mm}$ size. The pelleted feeds were sun dried in order to avoid moisture.

\section{Experimental Design}

Ten bowls were arranged and each of the bowls were stocked with 15 fingerlings and the bowls was labeled A1, A2, B1, B2, C1, C2, D1, D2, E1, E2 appropriately. The total weight and the total length of the fingerlings were determined per bowl using an electric weighing balance, thread and meter rule. The composition of experimental diets is presented in table 3.1

\section{Proximate Analysis}

Fish carcass compositions were analyzed before and after the experiment for crude protein; dry matter and ether extract which were determined according to the Association of Analytical Chemists Method (A.O.A.C., 2000). This was carried out in College of science at Afe Babalola University (ABUAD), Ado Ekiti, Ekiti State.. 
Table 3.1: The composition of experimental diet of Clariasgariepinus fingerlings fed graded levels of dietary protein.

\begin{tabular}{|l|l|l|l|l|l|}
\hline Feed ingredients & D1 35\% & D2 40\% & D3 45\% & D4 50\% & D5 55\% \\
\hline Fishmeal & 23.74 & 18.69 & 13.64 & 8.50 & 3.54 \\
\hline Soybean & 23.74 & 18.69 & 13.64 & 8.50 & 3.54 \\
\hline Rice bran & & & & & \\
\hline Maize & 26.27 & 31.31 & 36.86 & 41.41 & 46.46 \\
\hline Methionine & 22.77 & 27.81 & 32.86 & 37.91 & 42.96 \\
\hline Lysine & 5.00 & 5.00 & 5.00 & 5.00 & 5.00 \\
\hline Vitamin C & 5.00 & 5.00 & 5.00 & 5.00 & 5.00 \\
\hline Salt & 5.00 & 5.00 & 5.00 & 5.00 & 5.00 \\
\hline Vegetable oil & 5.00 & 5.00 & 5.00 & 5.00 & 5.00 \\
\hline Starch (binder) & 0.25 & 0.25 & 0.25 & 0.25 & 0.25 \\
\hline & 1.00 & 1.00 & 1.00 & 1.00 & 1.00 \\
\hline
\end{tabular}

Growth Performance and Nutrient Utilization Parameters

Growth was estimated in terms of mean weight, relative weight and specific growth rate (Bagenal, 1978).To determine the growth response of the fish, and the weight gain was recorded every week. From this, feed conversion ratio (FCR), specific growth rate (SGR), mean weight gain (MWG) Daily weight gain (DWG), percentage weight gain (PWG), daily feed intake growth performance, protein intake, food efficiency (FE), protein efficiency ratio (PER), nitrogen metabolism. The indices were calculated using the following formulae:

Mean Weight Gain (MWG) MWG =Mean final body weight $(\mathrm{g})$ - Mean initial body weight $(\mathrm{g})$

Relative Weight Gain (RWG)

$\mathrm{RWG}=$ Average Weight Gain $(\mathrm{g})$

Number of days (day)

Specific Growth Rate (SGR)

$\mathrm{SGR}=\underline{(\operatorname{LogeW} 1(\mathrm{~g})-\text { LogeW2 }(\mathrm{g}) \times 100}$

$$
\text { T2 - T1 (day) }
$$

Where, $\mathrm{e}=$ natural logarithm

$\mathrm{T} 2-\mathrm{T} 1=$ experimental period

$\mathrm{W} 1=$ initial weight

$\mathrm{W} 2$ = final weight

Nutrient utilization indices were expressed as follows;

Feed Conversion Ratio (FCR)

$\mathrm{FCR}=\underline{\text { Feed eaten in dry mass }(\mathrm{g})}$

Weight gain $(\mathrm{g})$ 
Protein Efficiency Ratio (PER)

$$
\mathrm{PER}=\frac{\text { Mean weight gain }}{\text { Protein intake }}
$$

Protein intake $=\underline{\text { Total feed intake }}$

Protein content of feed

Nitrogen metabolism $=[(0.54)(b-a) h] / 2$

$\mathrm{a}=$ initial weight, $\mathrm{b}=$ final weight, $\mathrm{h}=$ experimental period (days) and $0.54=$ experimental constant.

Statistical Analysis

All data collected were subjected to analysis of variance (ANOVA). Comparisons among diets means were carried out by Duncan Multiple Range Test (Duncan, 1955) at significant level of 0.05.

\section{RESULTS AND DISCUSSION}

Proximate Composition of Experimental Diets

The result of proximate composition of experimental diets of Clarias gariepinus fingerlings fed graded levels of dietary protein are presented in table 4.1. It was observed that highest crude protein was recorded in diet D1 (35\%) while the lowest in diet D5 (55\%). The highest crude fiber was recorded in diet D1 (35\%) while lowest crude fiber was obtained in diet D4 (50\%). The highest fats was obtained in diet D2 (40\%). The highest Ash contents was observed in diet D4 (50\%) while the lowest was observed in D1 (35\%). The highest carbohydrates was observed in diet D2 (40\%) while the lowest was observed in diet D1 (35\%). The highest moisture content was observed in Diet D2 $(40 \%)$ while the lowest moisture contents was observed in diet D1 (35\%).

Table 4.1: Proximate composition of experimental diets of Clarias gariepinus fingerlings fed graded levels of dietary protein.

\begin{tabular}{|l|l|l|l|l|l|}
\hline Dry matters & D1 35\% & D2 40\% & D3 45\% & D4 50\% & D5 55\% \\
\hline Analyzed Crude Protein & 32.94 & 27.89 & 22.75 & 15.25 & 11.00 \\
\hline Crude fiber & 8.48 & 8.36 & 8.21 & 7.90 & 8.20 \\
\hline Fats & 5.50 & 5.56 & 5.00 & 5.23 & 5.14 \\
\hline Ash & 11.49 & 11.93 & 12.52 & 12.75 & 12.73 \\
\hline Carbohydrate & 13.10 & 13.76 & 13.21 & 13.61 & 13.16 \\
\hline Moisture & 13.10 & 13.76 & 13.21 & 13.61 & 13.16 \\
\hline
\end{tabular}

Water Quality Parameter

The summary of physico- chemical parameters of the water used for the experiment are presented in table 4.2 shows. The temperature recorded was $25.86 \pm 0.94^{0} \mathrm{C}$, the $\mathrm{pH}$ values was $6.89 \pm 0.17$ and the dissolve oxygen recorded was $5.38 \pm 0.32 \mathrm{mg} / \mathrm{l}$.

Table 4.2: Summary of Physico- chemical parameters of water used for the experiment.

\begin{tabular}{|l|l|}
\hline Parameter & Mean Values \\
\hline Temperature $\left(0^{\circ} \mathrm{C}\right)$ & $25.86 \pm 0.94$ \\
\hline $\mathrm{p}^{\mathrm{H}}$ & $6.89 \pm 0.17$ \\
\hline Dissolve oxygen & $5.38 \pm 0.32$ \\
\hline \hline
\end{tabular}


Proximate Composition of Fish Carcass

The proximity composition of Clarias gariepinus fingerling carcass is presented in table 4.3. The highest ash content was recorded in Diet 4 (50\%) while the lowest ash content was recorded in Diet $2(40 \%)$ while the highest moisture content was recorded in Diet $2(40 \%)$ while the lowest content was recorded in Diet 1 (35\%), the highest crude protein was recorded in Diet $5(55 \%)$ while Diet 2 records the lowest crude protein. The highest percentage fat content was recorded in Diet $3(45 \%)$ while Diet $4(50 \%)$ has the lowest percentage of fat content. The soluble carbohydrate percentage was high in Diet $3(45 \%)$ and the lowest soluble carbohydrate percentage was recorded in Diet 5 $(55 \%)$.

Table 4.3: Proximate composition of the fish carcass

\begin{tabular}{|l|l|l|l|l|l|l|}
\hline Parameter & Initial & D1 & D2 & D3 & D4 & D5 \\
\hline Ash \% & 10.23 & 10.56 & 9.88 & 11.32 & 11.56 & 10.25 \\
\hline Moisture \% & 6.43 & 8.04 & 12.99 & 8.12 & 8.11 & 11.15 \\
\hline Crude Protein \% & 33.39 & 43.50 & 43.06 & 40.98 & 47.00 & 48.88 \\
\hline Fat \% & 9.16 & 11.20 & 11.85 & 12.35 & 10.12 & 11.18 \\
\hline Carbohydrate \% & 12.32 & 26.7 & 22.22 & 27.23 & 23.21 & 18.54 \\
& & & & & & \\
\hline
\end{tabular}

Growth of experimental fish

Body weight of Experimental Fish

Average body weight per week (grams) of Clarias gariepinus fingerlings is presented in table 4.4. The fish fed with $35 \%$ diet has $3.15 \mathrm{~g}$ as its initial average body weight and final average body weight is $5.0 \mathrm{~g}$. Fish with $40 \%$ of the experimental diet has $4.97 \mathrm{~g}$ as its initial average body weight and $10.1 \mathrm{~g}$ as its final average body weight, Fish fed with $45 \%$ of the experimental diet has $3.13 \mathrm{~g}$ as its initial average body weight and $6.1 \mathrm{~g}$ as its final average body weight, Fish fed with $50 \%$ of the experimental diets has $3.09 \mathrm{~g}$ as its initial average body weight $7.0 \mathrm{~g}$ as its final average body weight and lastly, Fish fed with $55 \%$ of the experimental diet has $4.1 \mathrm{~g}$ as its initial average body weight and $7.5 \mathrm{~g}$ as its final average body weight.

\section{Body Length of Experimental Fish}

Average body length per week $(\mathrm{cm})$ of Clarias gariepinus fingerlings fed with experimental diets were presented in table 4.5 . Fish fed with $35 \%$ diet has $11.6 \mathrm{~cm}$ as initial average body length and $13.7 \mathrm{~cm}$ as its final average body length. Fish fed with $40 \%$ of the experimental diet has $12.8 \mathrm{~cm}$ as its initial average body length and $15.8 \mathrm{~cm}$ as its final body length. Fish fed with $45 \%$ of the experimental diet has $11.5 \mathrm{~cm}$ as its initial average body length and $12.2 \mathrm{~cm}$ as the final average body length. Fish fed with $50 \%$ of the experimental diet has $12.4 \mathrm{~cm}$ as initial average body length and $13.3 \mathrm{~cm}$ as its final average body length and fish fed with $55 \%$ of the experimental diet has $12.5 \mathrm{~cm}$ as its initial average body length and $14.9 \mathrm{~cm}$ as its final average body length. 
Table 4.4: weekly average body weight $(\mathrm{g})$ of fish fed with all experimental diets and weeks.

\begin{tabular}{|l|l|l|l|l|l|l|l|l|}
\hline DIETS & 1 & 2 & 3 & 4 & 5 & 6 & 7 & 8 \\
\hline D1 35\% & $\begin{array}{l}3.15 \\
\pm 0.19^{\mathrm{e}}\end{array}$ & $\begin{array}{l}3.22 \\
\pm 0.25^{\mathrm{d}}\end{array}$ & $\begin{array}{l}3.52 \\
\pm 0.20^{\mathrm{d}}\end{array}$ & $\begin{array}{l}3.52 \\
\pm 0.20^{\mathrm{d}}\end{array}$ & $\begin{array}{l}3.81 \\
\pm 0.36^{\mathrm{c}}\end{array}$ & $\begin{array}{l}4.47 \\
\pm 0.39^{\mathrm{c}}\end{array}$ & $\begin{array}{l}4.62 \\
\pm 0.50^{\mathrm{b}}\end{array}$ & $\begin{array}{l}5.0 \\
\pm 0.63^{\mathrm{a}}\end{array}$ \\
\hline D2 40\% & $\begin{array}{l}4.97 \\
\pm 0.67^{\mathrm{b}}\end{array}$ & $\begin{array}{l}4.97 \\
\pm 0.67^{\mathrm{b}}\end{array}$ & $\begin{array}{l}5.78 \\
\pm 0.42^{\mathrm{d}}\end{array}$ & $\begin{array}{l}6.22 \\
\pm 0.82^{\mathrm{a}}\end{array}$ & $\begin{array}{l}7.43 \\
\pm 0.5^{\mathrm{c}}\end{array}$ & $\begin{array}{l}8.4 \\
\pm 0.38^{\mathrm{e}}\end{array}$ & $\begin{array}{l}8.8 \\
\pm 0.63^{\mathrm{b}}\end{array}$ & $\begin{array}{l}10.1 \\
\pm 0.45^{\mathrm{d}}\end{array}$ \\
\hline D3 45\% & $\begin{array}{l}3.13 \\
\pm 0.20^{\mathrm{e}}\end{array}$ & $\begin{array}{l}3.38 \\
\pm 0.47^{\mathrm{d}}\end{array}$ & $\begin{array}{l}3.92 \\
\pm 0.68^{\mathrm{b}}\end{array}$ & $\begin{array}{l}4.36 \\
\pm 0.22^{\mathrm{e}}\end{array}$ & $\begin{array}{l}5.33 \\
\pm 0.32^{\mathrm{d}}\end{array}$ & $\begin{array}{l}5.23 \\
\pm 0.55^{\mathrm{c}}\end{array}$ & $\begin{array}{l}5.66 \\
\pm 0.71^{\mathrm{a}}\end{array}$ & $\begin{array}{l}6.1 \\
\pm 0.77^{\mathrm{a}}\end{array}$ \\
\hline D4 50\% & $\begin{array}{l}3.79 \\
\pm 0.16^{\mathrm{e}}\end{array}$ & $\begin{array}{l}4.26 \\
\pm 0.5^{\mathrm{d}}\end{array}$ & $\begin{array}{l}5.16 \\
\pm 0.5^{\mathrm{d}}\end{array}$ & $\begin{array}{l}5.9 \\
\pm 0.63^{\mathrm{c}}\end{array}$ & $\begin{array}{l}6.86 \\
\pm 0.39^{\mathrm{d}}\end{array}$ & $\begin{array}{l}6.86 \\
\pm 0.39^{\mathrm{d}}\end{array}$ & $\begin{array}{l}7.46 \\
\pm 0.81^{\mathrm{b}}\end{array}$ & $\begin{array}{l}7.7 \\
\pm 0.92^{\mathrm{a}}\end{array}$ \\
\hline D5 55\% & $\begin{array}{l}4.1 \\
\pm 0.54^{\mathrm{c}}\end{array}$ & $\begin{array}{l}4.46 \\
\pm 0.55^{\mathrm{c}}\end{array}$ & $\begin{array}{l}4.86 \\
\pm 0.55^{\mathrm{c}}\end{array}$ & $\begin{array}{l}5.53 \\
\pm 0.87^{\mathrm{a}}\end{array}$ & $\begin{array}{l}6.6 \\
\pm 0.67^{\mathrm{b}}\end{array}$ & $\begin{array}{l}7.03 \\
\pm 0.71^{\mathrm{b}}\end{array}$ & $\begin{array}{l}7.56 \\
\pm 0.45^{\mathrm{d}}\end{array}$ & $\begin{array}{l}7.5 \\
\pm 0.39^{\mathrm{e}}\end{array}$ \\
\hline
\end{tabular}

a,b,c,d,e Mean and SD within the same roll and followed by the same superscript are not significantly different $(\mathrm{p}>0.05)$.

Table 4.5: Weekly average body length $(\mathrm{cm})$ of fish fed with all experimental diets.

\begin{tabular}{|c|c|c|c|c|c|c|c|c|}
\hline & \multicolumn{4}{|c|}{ WEEKS } & \\
\hline DIETS & 1 & 2 & 3 & 4 & 5 & 6 & 7 & 8 \\
\hline D1 $(35 \%)$ & $\begin{array}{l}11.6 \\
\pm 0.39^{d}\end{array}$ & $\begin{array}{l}11.7 \\
\pm 0.45^{\mathrm{c}}\end{array}$ & $\begin{array}{l}11.8 \\
\pm 0.39^{d}\end{array}$ & $\begin{array}{l}12.2^{\mathrm{b}} \\
\pm 0.5^{\mathrm{b}}\end{array}$ & $\begin{array}{l}12.4 \\
\pm 0.59^{b}\end{array}$ & $\begin{array}{l}12.6 \\
\pm 0.55^{\mathrm{b}}\end{array}$ & $\begin{array}{l}13.3 \\
\pm 0.87^{\mathrm{a}}\end{array}$ & $\begin{array}{l}13.7 \\
\pm 0.84^{\mathrm{a}}\end{array}$ \\
\hline D2 (40\%) & $\begin{array}{l}12.8 \\
\pm 0.55^{\mathrm{c}}\end{array}$ & $\begin{array}{l}13.1 \\
\pm 0.74^{b}\end{array}$ & $\begin{array}{l}13.5 \\
\pm 0.59^{c}\end{array}$ & $\begin{array}{l}13.7 \\
\pm 0.55^{\mathrm{c}}\end{array}$ & $\begin{array}{l}13.5 \\
\pm 0.39^{d}\end{array}$ & $\begin{array}{l}13.8 \\
\pm 0.77^{\mathrm{b}}\end{array}$ & $\begin{array}{l}15.4 \\
\pm 1.63^{\mathrm{a}}\end{array}$ & $\begin{array}{l}15.8 \\
\pm 1.61^{\mathrm{a}}\end{array}$ \\
\hline D3 (45\%) & $\begin{array}{l}11.5 \\
\pm 0.50^{d}\end{array}$ & $\begin{array}{l}11.7 \\
\pm 0.45^{\mathrm{e}}\end{array}$ & $\begin{array}{l}11.6 \\
\pm 0.55^{\mathrm{d}}\end{array}$ & $\begin{array}{l}12.2 \\
\pm 0.67^{\mathrm{c}}\end{array}$ & $\begin{array}{l}12.0 \\
\pm 0.50^{\mathrm{d}}\end{array}$ & $\begin{array}{l}12.1 \\
\pm 0.74^{b}\end{array}$ & $\begin{array}{l}12.4 \\
\pm 0.81^{\mathrm{a}}\end{array}$ & $\begin{array}{l}12.2 \\
\pm 0.59^{\mathrm{d}}\end{array}$ \\
\hline D4 (50\%) & $\begin{array}{l}12.4 \\
\pm 0.50^{c}\end{array}$ & $\begin{array}{l}12.6 \\
\pm 0.55^{\mathrm{c}}\end{array}$ & $\begin{array}{l}12.8 \\
\pm 0.63^{b}\end{array}$ & $\begin{array}{l}12.9 \\
\pm 0.55^{\mathrm{c}}\end{array}$ & $\begin{array}{l}13.1 \\
\pm 0.22^{d}\end{array}$ & $\begin{array}{l}12.6 \\
\pm 0.55^{\mathrm{c}}\end{array}$ & $\begin{array}{l}12.9 \\
\pm 0.59^{\mathrm{c}}\end{array}$ & $\begin{array}{l}13.3 \\
\pm 0.84^{\mathrm{a}}\end{array}$ \\
\hline $\begin{array}{l}\text { D5 } \\
(55 \mathrm{~g})\end{array}$ & $\begin{array}{l}12.5 \\
\pm 0.39^{\mathrm{e}}\end{array}$ & $\begin{array}{l}12.7 \\
\pm 0.67^{b}\end{array}$ & $\begin{array}{l}12.9 \\
\pm 0.45^{\mathrm{d}}\end{array}$ & $\begin{array}{l}13.1 \\
\pm 0.39^{\mathrm{e}}\end{array}$ & $\begin{array}{l}13.1 \\
\pm 0.50^{c}\end{array}$ & $\begin{array}{l}13.8 \\
\pm 0.63^{b}\end{array}$ & $\begin{array}{l}14.6 \\
\pm 1.45^{\mathrm{a}}\end{array}$ & $\begin{array}{l}14.9 \\
\pm 1.45^{\mathrm{a}}\end{array}$ \\
\hline
\end{tabular}

a,b,c,d,e Mean and SD within the same roll and followed by the same superscript are not significantly different $(\mathrm{p}>0.05)$.

\section{Nutrient Utilization of Experimental Fish}

The growth performance and survival of the experimental fish were presented in Table 4.6. In fish fed with D1 (35\%) the growth rate increases from mean initial weight of $3.15 \mathrm{~g}$ to mean final weight $5.0 \mathrm{~g}$ gives percentage weight gain of $20 \%$. In the fish fed with D2 (40\%), the mean initial weight increases from $4.97 \mathrm{~g}$ to mean final weight $10.1 \mathrm{~g}$ and gives a percentage weight gain of $15.3 \%$. Fish fed with D3 (45\%) the mean initial weight increases from 3.13g to the mean final weight of $6.1 \mathrm{~g}$ 
with percentage gain 19.9\%. Fish fed with D4 (50\%), the mean initial weight increases from $3.79 \mathrm{~g}$ to $7.7 \mathrm{~g}$ which gives $20 \%$ as the percentage gained weight. Fish fed with D5 (55\%), the mean initial weight increases from $4.1 \mathrm{~g}$ to $7.5 \mathrm{~g}$ which percentage weight gain gives $20 \%$..The overall specific growth rate for each experimental diet were calculated, fish fed $40 \%$ diet (D2) and $50 \%$ diet (D4) has the highest specific growth rate followed by (D3) $45 \%$ diet, (D5) $55 \%$ diet and then followed by $35 \%$ diet (D1) which has the lowest specific growth rate. There was high rate of mortality in all the experiment diets. Mortality rate for diet D1 (73\%), D2 (40\%), D3 (53\%), D4 (47\%) while D5 $(53 \%)$.

The highest survival rate was observed in D2 (60\%), follow by D4 (53\%), D3 (47\%), D5 (47\%) while the lowest survival rate was observed in diet D1 (27\%).

Table 4.6: Growth performance and survival of the experimental fish

\begin{tabular}{|l|l|l|l|l|l|}
\hline Parameters & Diet 1 & Diet 2 & Diet 3 & Diet 4 & Diet 5 \\
\hline Experimental period (days) & 62 & 62 & 62 & 62 & 62 \\
\hline Number of fish per bowl & 15 & 15 & 15 & 15 & 15 \\
\hline Mean initial weight (g) & 3.15 & 4.97 & 3.13 & 3.79 & 4.1 \\
\hline Mean final weight (g) & 5.0 & 10.1 & 6.1 & 7.7 & 7.5 \\
\hline Mean weight gain (MWG) (g) & 4.1 & 7.54 & 4.62 & 5.8 & 5.8 \\
\hline Daily weight gain (DWG) (g) & 0.82 & 1.51 & 0.92 & 1.16 & 1.16 \\
\hline Percentage weight gain \% & 20 & 15.3 & 19.9 & 20 & 20 \\
\hline Survival rate \% & 27 & 60 & 47 & 53 & 47 \\
\hline Mortality rate \% & 73 & 40 & 53 & 47 & 53 \\
\hline Specific growth rate (SGR) (\%) & 0.32 & 0.49 & 0.47 & 0.49 & 0.42 \\
\hline Protein Efficiency ratio & 0.43 & 0.61 & 0.58 & 0.61 & 0.53 \\
\hline Feed conversion ratio & 2.02 & 2.18 & 2.31 & 2.47 & 2.83 \\
\hline
\end{tabular}

\section{DISCUSSION}

The physico-chemical parameters of the water used with temperature recorded as $25.86 \pm 0.94, \mathrm{pH}$ value as $6.89 \pm 0.17$ and the dissolved oxygen as $5.38 \pm 0.32$ which is close to the values of Oso and Fagbuaro, (2008) and falls within the optimum limit for fish production, therefore making the water quality suitable for fish production.

From this result, fish was chosen randomly from the bowls. The fish showed good appetite to all the diet, attested to by the increase in body weight gain, increases in total length. It was observed that there was a general increase in weight gain from the first week to the last week of the experiment. It was observed that fish fed with $40 \%$ of the experimental diet has the highest body weight (10.1) and fish fed with $35 \%$ of the experimental diet has the lowest average body weight (5.0). It was also observed from the result that the fish fed with $40 \%$ diet has the highest length and the fish fed with $35 \%$ diet has the lowest body length. The satisfactory performance of fish fed with experimental diet shows that the highest Mean Weight Gain (MWG), Daily Weight Gain (DWG), Specific Growth Rate (SGR) was with fish fed $40 \%$ of experimental diet. 
The greatest specific growth rate, were recorded in fish fed with $40 \%$ and $50 \%$ of experimental diet and the least was achieved in fish fed with 35\%of experimental diet which has the lowest specific growth rate. This show that the highest survival rate was achieved in Diet D2 and D4 while the lowest survival rate was achieved in Diet D1.

The greatest feed conversion ratio was observed in the diet D5. It was observed that the best growth response was achieved in the fish fed with experimental diet D2 (40\%) and D4 (50\%).

The percentage weight gain was excellent throughout the experimental period. This could be as a result of good handling and good water quality management and the suitability of experimental diets. The water quality parameters obtained were within the recommended range for culture of (Clarias gariepinus Table 4.2).

Data obtained from the experiment were subjected to one way Analysis of Variance (ANOVA) using SPSS 20.0 version. Where the ANOVA revealed significant differences $(\mathrm{P}<0.05)$, Duncan's New Multiple Range Test was used to compare differences among individual treatment means.

The statistical analysis presented in this study shows that initial body weight at all experimental treatments differ significantly $(\mathrm{P}<0.05)$. The growth performance (mean final body weight, mean weight gain, \% weight gain, and specific growth rate) was significantly $(\mathrm{P}<0.05)$ different. Diet utilization (FCR and PER) was significantly $(\mathrm{P}<0.05)$ affected by the level of the experimental diets. The proximate composition of the experimental diets in the present study revealed that the crude protein content value was different.

\section{CONCLUSION}

From the results of this study, it was observed that when different experimental diets were fed to the Clarias gariepinus fingerlings, the growth and nutrient utilization indices were achieved in fish fed with experimental diet $40 \%$. The fish body cannot use all of the available protein for protein purposes after the optimum level has been reached (Phillips, 1972). Akegbejo-Samsons (1999) reported that excess protein could reduce growth performance due to energy requirement for metabolism, rather for protein deposition. The low food conversion ratio values in all the treatments are indicative of the capability of this species to accept and utilize compounded diets as reported by Fagbenro et al., (1986) in a related study. The higher protein efficiency ration and nitrogen metabolism followed the same trend as the growth indices. Protein was more efficiently utilized by C. gariepinus at $40 \%$ crude protein level than others. This trend is in tandem with results observed by Degani et al., (1989) on C. lazera.In view of the results obtained in this work. It is believed that a compounded diet of $40 \%$ crude protein would provide nutrients that will ensure optimum growth of $C$.gariepinus in production systems without natural food.

The statistical analysis carried out shows that fish fed with the experimental diets actively grow efficiently without external sign of nutritional deficiency.

The present study therefore can provide useful assistance to fish farmers especially in the culture and management of catfish (C. gariepinus) in Ekiti-state.

\section{RECOMMENDATION}

The research reveal that the specific growth rate, growth performance, survival rate and proximate composition of fish carcass of the fingerlings fed with $35 \%$ diet were significantly $(p>0.05)$ lower than those fed on other dietary levels.

The fingerlings responded nutritionally better to $40 \%$ diets than the other supplemented diets. With the success of this diet study, it is therefore recommended that feedgraded dietary protein level can be used as nutrient utilization when feeding is needed in the African catfish diet (Clarias gariepinus). 


\section{REFERENCES}

I. A. Abdel-Warith, S.J Davies. and P.Russell .Inclusionof a commercial poultry by- product mealas a protein replacement of fish meal in practical diets for the African catfish, Clarias gariepinus. Aquaculture Research, Vol.32, pp.296-306, 2001.

II. M .Z.Ali,. Dietary protein and energy interactions in African catfish Clarias gariepinus (Burchell, 1822).Institute of Aquaculture University of Starling, Scotland, United Kingdom,. PhD Theses 217p, (2001)

III.D.P Bureau, A.M Harris. And C.Y Cho. Apparent digestibility of rendered animal protein ingredients for rainbow trout

(Oncorhynchus mykiss).Aquaculture Vol.180, pp. 345-358, 1999

IV.D.P Bureau, A.M Harris D.J.Bevan, L.A.Simmons, P.A.Azeve- do and C.Y Cho..Feather meals and meat and bone meals from different origins as protein sources in rainbow trout (Oncorhynchus mykiss) diets. Aquaculture Vol.181,pp.281-291. 2000

V. S. J Davies, and A.Gouveia, Response of common carp fry diets containing a pea seed meal (Pisum sativum) subjected to different thermal processing methods. Elsevier.Vol..305 (1-4), pp.117- 123. 2010

VI.FAO, 2010. Food and Agricultural Organization of the United Nations World Review of Fisheries and Aquaculture 2010. Available at: http: // www. fao. org /docrep/ 013 / i1820e / i1820e01.pdf. Accessed June 15, 2012.

VII. E.A Fasakin, R.D Serwata and S.J Davies.Comparative utilization of rendered animal derived products with or without composite mixture of soybean meal in hybrid tilapia (Oreochromis niloticus, Oreochromis mossambicus) diets. Aquaculture Vol.249,pp.329-338. 2005

VIII. L.G Fowler. Poultry by-product meal as a dietary protein sources in fall chinook salmon. Aquaculture Vol.99, pp.309- 321,1991

IX. U. U Gabriel, O. A Akinrotimi, D. O Bekibele, D. N Onunkwo,. and P.E Anyanwu,. Locally produced fish feed: potentials for Aquaculture development in subsaharan Africa. African Journal of Agricultural Research Vol.2 (7), pp287-295,2007.

X. M.L Gallagher. and G.Degani. Poultry meal and poultry oil as sources of protein and lipid in the diet of European eels, Anguilla anguilla. Aquaculture Vol.73,pp.177-187.1988

XI.D.M Gatlin. III and R.W Hardy Manipulations of diets and feeding to reduce losses of nutrients in intensive Aquaculture. In: Aquaculture and the Environment in the United States (edby J.R. Tomasso), pp.155-165. 2002. World Aquaculture Society, Baton Rouge, LA,USA.

XII. D.M Gatlin, Principles of Fish Nutrition. Southern Region Agricultural Centre SRAC Publication No. 5003, pp: 8. 2010.

XIII. B. Glencross, W.Hawkins, E. Veitch, K.Dods, P. McCafferty and R.Hauler. The influence of dehulling efficiency on the digestible value of lupin(Lupinusangustifolius) kernel meal 
when fed to rainbow trout (Oncorhynchus mykiss). Aquaculture Nutrition Vol.13,pp.462-470. 2007

XIV. R.W Hardy and A.G.Tacon C.and V.,1840. 2002. Fish meal: historical uses,productiontrends and future outlook for sustainable supplies. In: Responsible

MarineAquaculture (ed. by R.R. Stickney and J.P. McVey), p. 311-325.CABI Publishing, Wallingford, UK.

XV. H.Hogendoorn.The African catfish, (Clarias lazera ^ a new species for Aquaculture. Wageningen Agricultural University, Wageningen, the Netherlands PhD Theses,, pp.135. (1983)

XVI. D.M, Jamu and O.A Ayinla. Potential for the development of Aquaculture in Africa NAGA 26: 9-13. (2003)

XVII.J. Laporte, S.L Woodgate, S.J Davis,and A.Gouveia, Combining blood meal with other animal protein sources in compound aqua feed. International Aqua feed Vol.7(8),pp.12-18. 2009

XVIII. R.T Lovell.Use of soybean meal in diets for Aquaculture species. Journal of Aquatic Production Vol.2,pp.27-52. 1988

XIX. O.M Millamena. Replacement of fish meal by animal by-product meals in practical diet for grow-out culture of grouper Epinepheluscoioides. Aquaculture Vol.204,pp.75-84. 2002

XX. P.E Ndimele, F.G. Owodeinde, C.A. Kumolu-Johnson, A.A. Jimoh,O.O.Whenu and O.B. Onyenania,. Growth performance of the reciprocal hybrids of Clarias gariepinus (Burchell, 1822) and Heterobranchus bidorsalis (Valenciennes, 1840).Current Research. Journal of Biological Science Vol.3, pp.137-140. 2011

XXI. J.A Oso ,J.B. Edward,O.A Ogunleye, F.A Majolagbe Growth Response and Feed Utilization of Clarias gariepinus Fingerlings Fed with Bambara Groundnut as protein source. Journal of Natural Sciences Research Vol.3(5) pp.84-90. 2013

XXII. J.A Oso and O. Fagbuaro. An Assessment of the Physico-Chemical Properties of a Tropical Reservoir, Southwestern, Nigeria. Journal of Fisheries International Vol.3(2) pp. 42-45, 2008 ISSN: 1817-3381.

XXIII. F.G Owodeinde, and P.E. Ndimele,.Survival, growth and feed utilization of two clariid catfish (Clarias gariepinus, Burchell 1822 and Heterobranchus bidorsalis, Geoffroy, 1809) and their reciprocal hybrids. Journal of Applied Ichthyology, 2011

XXIV. C.M Parsons, F Castanon and Y.Han. Protein and amino acid quality of meat and bone meal..Poultry Science Vol.76 pp.361-368. (1997)

XXV. J. Pongmaneerat and T.Watanabe..Nutritive value of protein of feed ingredients for carp Cyprinus carpio. Nippon Suisan Gakkaishi Vol.57 pp.503-510. (1991)

XXVI. S.Refstie, S. Helland and T.Storebakken . Adaptation to soybean meal in diets for rainbow trout(Oncorhynchus mykiss).Aquaculture Vol.153 pp263-272. 1997 
XXVII. S.Refstie,A.J. Roem and T. Storebakken .Feed consumption and conversion in Atlantic salmon (Salmosalar) fed diets with fish meal, extracted soybean meal or soybean meal with reduced content of oligosaccharide

XXVIII. s, trypsin inhibitor, lectine and soya antigens. Aquaculture Vol.162, pp 301-312. 1998

XXIX. Rodriguez-Sena M., Olivera M.A. and Carmona-Osalda C. (1996).Nutritional value of animal by-product meal in practical diets for Nile tilapia Oreochromis niloticus(L) fry. Aquaculture Research v27,p67-73.

XXX. G.L Rumsey, S.G Haghes and R.AWinfree.Chemical and nutritional evaluation of soya protein preparation as primary nitrogen source for rainbow trout (Oncorhynchus mykiss). Animal Feed Science Technology Vol.40,pp135-151. (1993)

XXXI. W.Stevens W..Replacement of fish meal with poultry by- product meal in diets for rainbow trout (Oncorhynchus mykiss) Aquaculture.Vol.124, pp 27-34. 1994

XXXII. M.A Soltan, M.A Hanafy,and M.I.A Wafa, Effect of replacing fish meal by a mixture of different plant protein sources in Nile Tilapia (Oreochromis niloticus L.) diets. Global Veterinaria Vol.2 (4),pp 157-164. 2008.

XXXIII. A.G.J Tacon and A.J Jackson Utilization of conventional and unconventional proteins ources in practical fish feeds. In: Nutrition and Feeding of Fish (ed. by C.B. Cowey, A.M. Mackie and J.G. Bell), pp.119-145. (1985)Academic Press, London, UK.

XXXIV. S.T Takagi,H. Hosokawa, S.Shimeno. and M.Ukawa Utilization of poultry byproduct meal in a diet for red sea bream Pagrusmajor. Nippon Suisan Gakkaishi Vol.66, pp 428-438. (2000)

XXXV. J.Verreth, E.H Eding, G.R.M. Rao,F. Huskens and H. Segner H. A review of feeding practices, growth and nutritional physiology in larvae of the catfishesClarias gariepinus and Clarias batrachus. Journal of the World Aquaculture Society Vol.24,pp.135-144. 1993

XXXVI. C.D Webster, D.H Yancey and J.H Tidwell..Eject of totally or partially replacing of fish meal with soybean meal in growth of blue catfish Ictalurusfurcatus. Aquaculture Research,Vol.103, pp.141-152. 1992

XXXVII. C.D Webster ,L.S Goodgame-Tie and J,H Tidwell .Total replacement of soybean meal with various percentages of supplemental methionine in diet for blue catfish Ictalurus furcatus. Aquaculture Research Vol.26,pp299-306. 1995 